\title{
VACATION HOMES, SECTION 280A AND BOLTON V. COMMISSIONER: THE RIGHT RESULT FOR THE WRONG REASONS
}

In response to widespread concern that many taxpayers were renting their vacation homes in order to deduct otherwise nondeductible, personal expenses, Congress in 1976 added section $280 \mathrm{~A}^{1}$ to the Internal Revenue Code. ${ }^{2}$ By this enactment, Congress sought to limit the deductibility of vacation home expenses when a vacation home is used for both rental and personal purposes ${ }^{3}$ by requiring taxpayers to allocate expenses associated with the vacation home between personal and rental

1. I.R.C. $\S 280$ A (1982).

2. Tax Reform Act of 1976, Pub. L. No. $94-455, \S 601,90$ Stat. 1520, 1569-72. See generally H.R. ReP. No. 658, 94th Cong., 1st Sess. 157-67, reprinted in 1976 U.S. CoDE CoNG. \& AD. NewS 2897, 3050-60; S. REP. No. 938, 94th Cong., 2d Sess. 144-55, reprinted in 1976 U.S. CODE CONG. \& AD. News 3439, 3576-87; StafF of Joint Comm. on TAXation, 94Th Cong., 2D Sess., General Explanation of the Tax Reform ACt of 1976, at 136-46 (Comm. Print 1976), reprinted in 1976-3 C.B. 148-58. For 1977 amendments, see Tax Reduction and Simplification Act of 1977, Pub. L. No. 95-30, § 306, 91 Stat. 126, 152-53; H.R. REP. No. 263, 95th Cong., Ist Sess. 29 (1977); S. REP. No. 66, 95th Cong., Ist Sess. $89-92$ (1977). For 1978 amendments, see Revenue Act of 1978, Pub. L. No. 95-600, § 701(h), 92 Stat. 2763, 2904; S. REP. No. 745, 95th Cong., 2d Sess. 19. 20 (1978). For 1981 amendments, see Black Lung Benefits Revenue Act of 1981, Pub. L. No. 97 119, § 113, 95 Stat. 1635, 1641-43. For 1982 amendments, see Urgent Supplemental Appropriations Act, 1982, Pub. L. No. 97-216, § 215(b), 96 Stat. 180, 194; Subchapter S Revision Act of 1982, Pub. L. No. 97-354, §5(a)(26), 96 Stat. 1669, 1694.

Although section $280 \mathrm{~A}$ applies to expenses of both home offices and vacation homes, this note discusses the application of section $280 \mathrm{~A}$ only to vacation homes.

President Reagan has recently proposed tax reform Iegislation that would eliminate the deduction for the real property taxes of a vacation home and also eliminate or significantly restrict the deduction for interest paid on indebtedness incurred to finance a vacation home, to the extent that the property is not held for the production of income. The President's Tax Proposals to the Congress for Fairness, Growth, and Simplicity, 62-66, 322-24 (May 29, 1985). Rather than eliminate the interest deduction related to the vacation home, the proposal would aggregate this interest with other interest expenses, limiting the aggregate deduction to $\$ 5000$ plus the taxpayer's net investment income. Id. at 323. The proposal does not address the integration of the proposed changes and section 280A. At present, no action has been taken on this proposal.

3. The Senate Finance Committee stated:

Where expenses attributable to a residence are treated as deductible business expenses, an opportunity exists to convert nondeductible personal, living and family expenses into deductible expenses. In the case of so-called "vacation homes" that are used both for personal purposes and for rental purposes, the committee believes that frequently personal motives predominate and the rental activities are undertaken to minimize the expenses of ownership of the property rather than to make an economic profit.

In marketing vacation homes, it has become common practice to emphasize that certain tax benefits can be obtained by renting the property during part of the year, while reserving the remaining portion for personal use. . . 
use. Although in framing section 280A Congress set out to provide objective rules for determining that allocation, recent controversy concerning the interpretation of the section ${ }^{4}$ demonstrates that Congress failed to draft the allocation rules with clarity.

In Bolton v. Commissioner ${ }^{5}$ the Ninth Circuit focused on the proper interpretation of the allocation rules set forth in section 280A. Rejecting the arguments advanced by the Internal Revenue Service (IRS), the court adopted an interpretation of the allocation rules favorable to taxpayers. ${ }^{6}$ The IRS has not acquiesced in Bolton and has continued to litigate the issue-thus far unsuccessfully. ${ }^{7}$ Because of the number of vacation homes and the importance of section $280 \mathrm{~A}$, the issue is of continuing importance. ${ }^{8}$

This note first illustrates the operation of section $280 \mathrm{~A}$ in order to establish the relationship between its different allocation rules. ${ }^{9}$ The note then discusses the interpretation adopted by the Bolton court and the conflicting position held by the IRS. ${ }^{10}$ An examination of the language of the statute and its legislative history follows, demonstrating that, contrary to the assertions of the Bolton court, Congress did not address the issue raised in Bolton when it enacted section 280A. ${ }^{11}$ Finally, the note argues that although the Bolton court's reasoning was not wellfounded, its decision was nonetheless correct. Relying on (1) the

... The committee believes that definitive rules should be provided to specify the extent to which personal use would result in the disallowance of certain deductions in excess of gross income. . . .

In addition, if there is any personal use of a vacation home, the portion of expenses allocable to rental activities should be limited to an amount determined on the basis of the ratio of time that the home is actually rented, to the total time [that the] vacation home is used during [the] taxable year for all purposes (i.e., rental, business, and personal activities).

S. REP. No. 938, supra note 2, at 151-52.

4. See infra notes 15-29 and accompanying text.

5. 694 F.2d 556 (9th Cir. 1982), affg 77 T.C. 104 (1981). The appellate court opinion includes the analysis contained in the Tax Court opinion and develops it more fully; accordingly this note focuses on the appellate court opinion.

6. Id. at 564-65.

7. See McKinney v. Commissioner, 83-2 U.S. Tax Cas. (CCH) \9655, at 88,349 (10th Cir. 1983) (following Bolton); Buchholz v. Commissioner, 46 T.C.M. (CCH) 608, 610 (1983) (following Bolton); Baker v. Commissioner, 45 T.C.M. (CCH) 635, 638 (1983) (following Bolton). These cases did not expand on the Bolton court's analysis of the issue. The IRS position is codified in 48 Fed. Reg. 33,320 (1983) (to be codified at Treas. Reg. $\$ 1.280 \mathrm{~A}-3(\mathrm{c})(4)$ ) (proposed July 21, 1983).

8. In 1983, there were 3,304,000 seasonal homes and homes held for occasional use. BUREAU of the Census, Current Housing Reports, Series H-150-83, Annual Housing Survey: 1983, Part A, General Housing Characteristics, Table A-1. Statistics are not maintained on the portion of these homes that are rented to others, but it is safe to assume that many seasonal and vacation homes are rented.

9. See infra notes 15-29 and accompanying text.

10. See infra notes $30-44$ and accompanying text.

11. See infra notes $45-59$ and accompanying text. 
legislative intent underlying section $280 \mathrm{~A},{ }^{12}$ (2) the fundamental distinction between tax and interest payments and other expenses, ${ }^{13}$ and (3) recognition of the owner's investment objective, ${ }^{14}$ the note concludes that the interpretation of section $280 \mathrm{~A}$ advanced by the IRS must be rejected.

\section{The Operation of Section 280A}

Section $280 \mathrm{~A}$ is a complex statute that prescribes a two-stage limitation on the deductibility of the maintenance and depreciation expenses of a vacation home. A taxpayer must first allocate expenses between rental use and personal use of the vacation home, pursuant to section $280 \mathrm{~A}(\mathrm{e})(1) .{ }^{15}$ Section $280 \mathrm{~A}(\mathrm{e})(1)$ sets a cap on the amount that can be deducted, limiting it to an amount equal to the product of the total expenses ${ }^{16}$ and the following fraction:

number of days rented at fair rental value

total number of days of use for any purpose. ${ }^{17}$

12. See infra notes $65-87$ and accompanying text.

13. See infra notes $88-96$ and accompanying text.

14. See infra notes $97-106$ and accompanying text.

This issue was also analyzed in Lang, Vacation Homes Revisited: Bolton Mistakenly Unbolts Door to Extra Deductions, 37 TAX LAw. 323 (1984). Professor Lang argued that Bolton was incorrectly decided and that the rule adopted in the case was both fundamentally unsound and incorrect in its interpretation of the statute. Id. at 324.

15. Section 280A(e) provides:

(e) EXPENSES ATtributable to ReNTAL-

(1) IN GENERAL.- In any case where a taxpayer who is an individual or an electing small business corporation uses a dwelling unit for personal purposes on any day during the taxable year (whether or not he is treated under this section as using such unit as a residence), the amount deductible under this chapter with respect to expenses attributable to the rental of the unit (or portion thereof) for the taxable year shall not exceed an amount which bears the same relationship to such expenses as the number of days during each year that the unit (or portion thereof) is rented at a fair rental bears to the total number of days during such year that the unit (or portion thereof) is used.

(2) EXCEPTION FOR DEDUCTIONS OTHERWISE ALLOWABLE.-This subsection shall not apply with respect to deductions which would be allowable under this chapter for the taxable year whether or not such unit (or portion thereof) was rented.

I.R.C. $\S 280 \mathrm{~A}(\mathrm{e})(1982)$.

16. Section $280 \mathrm{~A}(\mathrm{e})(1)$ refers to "expenses attributable to the rental of the unit" as subject to the allocation formula. The IRS has not interpreted that phrase to mean that only expenses incurred because of the rental of the unit are subject to the allocation formula. Rather, the IRS has interpreted that phrase to mean that "the total expenses paid or incurred with respect to the unit during the taxable year" are allocated between personal and rental use by means of the formula. 48 Fed. Reg. 33,320 (1983) (to be codified at Treas. Reg. $§ 1.280 \mathrm{~A}-3(\mathrm{c})(1)$ ) (proposed July 21, 1983). Thus, according to the IRS, there is only one allocation of all expenses between rental and personal use, and not a two-step limitation-the taxpayer first segregating expenses into those attributable and those not attributable to rental use of the home with a subsequent multiplication of the rental use expenses by the allocation formula. In fact, the allocation formula itself is an objective means of splitting total expenses into those attributable to personal use and those attributable to rental use.

17. I.R.C. $\S 280 \mathrm{~A}(e)(1)(1982)$. 
In this manner, deductible rental expenses are separated from nondeductible personal expenses. This allocation must be made if the vacation home is used for personal purposes during any part of the year. ${ }^{18}$

Section $280 \mathrm{~A}(\mathrm{e})(2)$ provides that expenses that are deductible regardless of whether a vacation home was rented shall be excluded from the rental expense limitation calculated by application of section $280 \mathrm{~A}(\mathrm{e})(1){ }^{19}$ Interest on indebtedness incurred to carry the vacation home, ${ }^{20}$ real estate taxes, ${ }^{21}$ and casualty losses ${ }^{22}$ are examples of such expenses. ${ }^{23}$

Once the expenses attributable to the rental use of a vacation home are calculated pursuant to section 280(e)(1), they are subjected to a second cap-calculated pursuant to section $280 \mathrm{~A}(\mathrm{c})(5)$-if sufficient personal use of the vacation home results in its classification as a "residence." 24 If the vacation home is found to be a residence, then the deductions attributable to the rental use of the home-as calculated pursuant to section $280 \mathrm{~A}(e)(1)^{25}$ - may not exceed the net rental income. ${ }^{26}$ Net rental imcome is calculated by subtracting from gross rental income those expenses that are deductible regardless of whether the home was rented. ${ }^{27}$ This limitation is imtended to prevent taxpayers from using a net loss from rental activities to offset other taxable income when per-

18. "Personal use" is defined in detail by I.R.C. $\$ 280$ A(d)(2)-(4) (1982).

19. I.R.C. $\S 280 \mathrm{~A}(\mathrm{e})(2)(1982)$.

20. Interest on the indebtedness incurred to carry the vacation home is deductible pursuant to I.R.C. $\$ 163$ (1982).

21. Real estate taxes on the vacation home are deductible pursuant to I.R.C. $\S 164$ (1982). (1982).

22. Casualty losses associated with the vacation home are deductible pursuant to I.R.C. § 165

23. These expenses are expressly made deductible by the Internal Revenue Code and arc exceptions to the general rule that personal expenses are not deductible.

24. This second limitation applies whenever personal use during the taxable year exceeds the greater of 14 days or $10 \%$ of the number of days the vacation home was rented at a fair rental during the taxable year; this constitutes sufficient personal use of the vacation home to warrant "residence" classification. I.R.C. $\S 280 \mathrm{~A}$ (d)(1) (1982).

25. See supra notes 16-17 and accompanying text.

26. I.R.C. $\S 280 \mathrm{~A}(\mathrm{c})(5)(1982)$.

27. See supra notes 20-23 and accompanying text for a discussion of deductions that are allowable regardless of whether there is rental use-interest, taxes, and casualty losses. Recall that these expenses were excluded from the $\S 280 \mathrm{~A}(\mathrm{e})(1)$ allocation.

The method of allocating interest and taxes to rental use is the subject of this note. As an example of how this two-stage limitation works, assume that total rental income was $\$ 3000$, total expenses excluding interest and taxes were $\$ 2000$, and total interest and taxes allocable to rental use were $\$ 2000$. Also assume that the vaeation home was used personally for 50 days and rented to third parties for 150 days-a total of 200 days. The two-step limitation would be calculated as follows:

Step one $(\S 280 \mathrm{~A}(\mathrm{e})(1))$ :

Total expenses excluding interest and taxes $\$ 2000 \times \frac{150 \text { days }}{200 \text { days }}=\$ 1500$ 
sonal use of the vacation home predominates. In such a situation, Congress believed that the vacation home must have been purchased primarily for personal enjoyment, and that any rental was undertaken only to defray the cost of ownership. ${ }^{28}$ Thus, this second limitation provides an objective substitute for determining when the primary purpose of owning the home is personal use. ${ }^{29}$

\section{THE IsSUE IN BOLTON}

The application of the second-stage "gross income" limitation of section $280 \mathrm{~A}(\mathrm{c})(5)$ was the central issue addressed in Bolton. ${ }^{30}$ As described above, section $280 \mathrm{~A}$ (c)(5) provides that the amount deducted for maintenance and depreciation expenses allocated to rental use of the property under section $280 \mathrm{~A}(\mathrm{e})(1)$ may not exceed the gross rental income reduced by the amount of interest and real estate taxes allocated to such use. ${ }^{31}$ Thus, although both interest and real estate taxes are deductible regardless of any rental use, the extent to which these are allocated to rental use will directly affect the deductibility of otherwise nondeductible maintenance and depreciation expenses. ${ }^{32}$ Section $280 \mathrm{~A}(\mathrm{c})(5)$, however, merely provides that the taxpayer must allocate interest and real estate taxes to the rental use of the property in applying the "gross income" limitation; it does not provide any formula for making the allocation. ${ }^{33}$ Examination of the facts in Bolton illustrates both the operation of section $280 \mathrm{~A}$ and the results produced by the different allocation methods used by the taxpayer and the IRS.

During the taxable year, the Boltons rented their vacation home for ninety-one days, used it personally for thirty days, and left it unoccupied

Step two (\$ 280A(c)(5)):

Rental income $\ldots \ldots \ldots \ldots \ldots \ldots \ldots \ldots \ldots \ldots \ldots \ldots \ldots \ldots \ldots \ldots \ldots \ldots \ldots$

Less interest and taxes allocated to rental use $\ldots \ldots \ldots \ldots \ldots \ldots \ldots \ldots \ldots, \frac{\$(2000)}{\$(1000)}$

Limitation on deductibility of other expenses .................... $\$(1000)$ Thus, of the $\$ 1500$ total expenses that were allocated to rental use under $\S 280 \mathrm{~A}$ (e)(1), excluding interest and taxes, only $\$ 1000$ is deductible as a result of the second limitation under $\$ 280 \mathrm{~A}(\mathrm{c})(5)$.

28. See supra note 3.

29. But see section $280 \mathrm{~A}(\mathrm{~g})$, which provides a de minimis exception. If the vacation home is rented for fewer than 15 days during the taxable year, then the taxpayer can neither recognize any rental income nor obtain any deductions except for those deductions that are allowable regardless of the rental use of the property-interest, taxes, and casualty losses.

30. Bolton, 694 F.2d at 558-59.

31. See supra notes 24-27 and accompanying text.

32. Gross rental income, the foundation of the limitation, is fixed in a particular instance. Thus, the amount of maintenance expenses deductible will vary according to the method chosen to allocate interest and taxes to rental use. The greater the allocation of interest and taxes to rental use, the smaller the deduction for maintenance expenses.

33. Bolton, 694 F.2d at 558-59. 
for 244 days. ${ }^{34}$ During that year, the Boltons made interest payments totalling $\$ 2854$ on indebtedness incurred to carry the property, paid property taxes of $\$ 621$, and incurred $\$ 2693$ in maintenance expenses. ${ }^{35}$ The Boltons received $\$ 2700$ in gross rents from the property during the year. ${ }^{36}$

In order to calculate the total deduction allowed under section $280 \mathrm{~A}$, the taxpayer must first allocate the ordinarily nondeductible maintenance expenses of $\$ 2693$ between rental and personal use. ${ }^{37}$ Employing the "days rented to total days used" formula of section $280 \mathrm{~A}(\mathrm{e})(1)$, $\$ 2020$ of the inaintenance expenses is attributable to the rental use of the vacation home. ${ }^{38}$ Next, the taxpayer must apply the "gross income" limitation of section $280 \mathrm{~A}(\mathrm{c})(5) .{ }^{39}$ To do so, the taxpayer must in some way allocate interest and real estate taxes between personal and rental use. The Boltons contended that this allocation should be based on the ratio of the total number of days rented to the number of days in the year. ${ }^{40}$ The Commissioner, on the other hand, argued that interest and taxes should be allocated to rental use by employing the same ratio used for maintenance expenses under section $280 \mathrm{~A}(\mathrm{e})(1)$-the nuinber of days rented to the number of days the property was actually used. ${ }^{41}$

The allocation method selected can make a significant difference in the total deduction available. The Boltons' approach would allow thein to deduct $\$ 1832$ of the $\$ 2020$ in allocated maintenance expenses; in contrast, the Commissioner's approach would allow them to deduct only

34. Id. at 557. Although the sum is 365 days, the year in question-1976-in fact contained 366 days. The court used 365 days because the parties had failed to specify the use of the property for the additional day. Bolton v. Commissioner, 77 T.C. 104, 105 n.1 (1981).

Because the period of personal use, 30 days, exceeded both 14 days and $10 \%$ of the 91 days that the vacation home was rented, there was sufficient personal use for the vacation home to be classified as a residence, thus triggering the section $280 A$ (c)(5) limitation. See supra notes 24-27 and accompanying text.

35. Bolton, 694 F.2d at 557.

36. Id.

37. I.R.C. $\$ 280 A(e)(1)$ (1982). See also supra notes $16-23$ and accoinpanying text.

38. Bolton, 694 F.2d at 558. The calculation is as follows:

91 days of rental use +30 days of personal use $=121$ days of use

$91 / 121=75 \% \times \$ 2693$ (total maintenance expenses) $=\$ 2020$.

39. See supra notes 24-27 and accompanying text.

40. Bolton, 694 F.2d at 559. The following result would obtain:

Gross rental income..................................\$\$2700

Less interest and property taxes allocated to rental use:

Total interest and property taxes $\ldots \ldots \ldots \ldots \ldots \ldots \ldots \ldots \ldots \ldots \$ \ldots 3475$

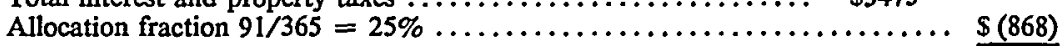

Rental income in excess of allocated

interest and property taxes $\ldots \ldots \ldots \ldots \ldots \ldots \ldots \ldots \ldots \ldots \ldots \ldots \ldots \ldots \ldots, \$ 1832$

Id. at n.8.

41. Id. at 559. This reasoning would obtain the following result: 
\$94. The court of appeals held that section 280A(e)(2) precludes the use for this purpose of the "days rented to total days used" formula contained in section $280 \mathrm{~A}(\mathrm{e})(1),{ }^{42}$ and rejected the Commissioner's interpretation as being in conflict with the plain meaning of the statute. ${ }^{43}$ Accordingly, the court of appeals affirmed the Tax Court decision and validated the interpretation advanced by the Boltons. ${ }^{44}$

\section{Analysis of Statute and Legislative History}

Neither the statute nor the legislative history specifically addresses the method of allocating interest and taxes. Section $280 \mathrm{~A}(\mathrm{e})(2)$ provides that "this subsection [(e)] shall not apply with respect to deductions" that are allowable without regard to the rental activity. ${ }^{45}$ From this, the Bolton court concluded that the plain language of section $280 \mathrm{~A}(\mathrm{e})(2)$ explicitly precludes the use, in allocating taxes and interest, of the "days rented to total days used" formula of section $280 \mathrm{~A}(\mathrm{e})(1) .46$

The language of section $280 \mathrm{~A}$, however, is not plain. One commentator has suggested that subsection (e)(2) was not intended to place as great a restriction on the subsection (e)(1) formula as the interpretation adopted in Bolton suggests. ${ }^{47}$ According to this coinmentator's view, subsection (e)(2) was merely designed to prevent subsection (e)(1) from limiting the deductibility of interest and taxes, and not to provide guidance on the applicability of the subsection (e)(1) formula to the alloca-

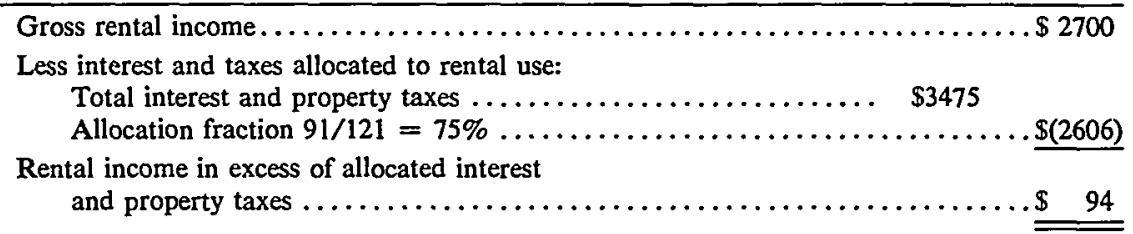

Id. at n.8.

42. Id. at 561 . For text of section $280 \mathrm{~A}(\mathrm{e})$, see supra note 15 .

43. Bolton, 694 F.2d at 561 .

44. Id. at 564-65.

45. I.R.C. $\S 280 \mathrm{~A}(\mathrm{e})(2)$. For the full text of section $280 \mathrm{~A}(\mathrm{e})$, see supra note 15 .

46. Bolton, 694 F.2d at 561. The court treated the Commissioner's interpretation as being in conflict with the plain meaning of the statute; the Commissioner argued instead that the meaning of subsection (e)(2) is not plain, and that other interpretations are possible. Id. The court nevertheless rejected those interpretations. Id. at n.11. The Commissioner had suggested that section $280 \mathrm{~A}$ was ambiguous, and that subsection (e)(2) could be interpreted to mean either that the taxpayer is to apply the entire amount of the interest and tax deductions against the gross income from rentals, or that none of the taxes and interest is to be applied against the gross rental income. Id. The court noted that these interpretations ignore the language in section $280 \mathrm{~A}$ (c)(5) directing the allocation of those deductions between rental and nonrental use. Id. Another suggestion-a "days not personally used to total days in the year" formula-was rejected by the court on the grounds that such a construction ignored the statute's equating of business use with days rented. $I d$.

47. Lang, supra note 14 , at 328 . 
tion of interest and taxes. ${ }^{48}$ This contention is undoubtedly correct to the extent that subsection (e)(2) was intended to prevent subsection (e)(1) from limiting the deductibility of interest and taxes. One may not ignore, however, the prophylactic language of subsection (e)(2). Section $280 \mathrm{~A}(\mathrm{e})(2)$ expressly states that "this subsection shall not apply with respect to deductions" that are allowable without regard to the rental activity-interest and taxes. Subsection (e)(2) thus explicitly renders all of subsection (e), including the allocation formula of subsection (e)(1), wholly inapplicable to interest and taxes. Although not the only possible interpretation, the court's interpretation of the statutory language is reasonable. In any event, the Commissioner's position does not receive support from the language of subsection (e); any support for the "days rented to total days used" formula must come from other sources.

The legislative history provides little support for a particular method of allocating interest and taxes. ${ }^{49}$ It does, however, provide evidence that the "days rented to total days used" formula was intended to apply only to expenses other than interest and taxes. Section $280 \mathrm{~A}(\mathrm{e})(1)$ provides that the taxpayer must allocate expenses "attributable to the rental of the unit" between rental and personal use based on that formula. ${ }^{\text {so }}$ The coinmittee reports clarify the meaning of expenses "attributable to the rental of the unit." The cominittee reports indicate that the general purpose of section $280 \mathrm{~A}$ is to limit deductions attributable to the rental of a vacation home. ${ }^{51}$ Although they do not address the subsection (e)(1) limitation directly, the passages in the reports that discuss the phrase "attributable to the rental activities" invariably illustrate its use solely in connection with those expenses that are deductible only because of rental use. Furthermore, the phrase "attributable to the rental of a vacation home" is defined by the committee reports so as to exclude interest and taxes-items deductible regardless of rental activities. ${ }^{52}$

48. Id. Professor Lang contends that section $280 \mathrm{~A}(\mathrm{e})(2)$ is not superfluous in light of section 280A(b): Section 280A(b) expressly allows the deduction of interest and taxes in cases where section 280A(a)'s general rule of disallowance applies. Professor Lang's point is that the section 280A(e)(1) limitation rule applies in situations not subject to section $280 \mathrm{~A}$ (a)'s general rule of disallowance. In such situations, section $280 \mathrm{~A}(\mathrm{e})(2)$ protects the full deductibility of interest and taxes that section 280A(e)(1) would otherwise limit despite section 280A(b). Id.

49. Both parties in Bolton conceded that the legislative history is unclear on the proper method of allocation. Bolton, 694 F.2d at 561-62.

50. See supra note 15 for complete text of section $280 \mathrm{~A}(\mathrm{e})(1)$.

51. S. REP. No. 938, supra note 2 , at 152 . The relevant passage provides:

The [Act] adds a new provision (sec. 280A) which, in general, provides a limitation on the amount allowable to a taxpayer for the deductions attributable to the rental of a vacation home if the taxpayer personally uses the home in excess of specified periods of tine during a taxable year.

Id. (emphasis added).

52. Id. at 153 . The Senate report provides: 
One passage in the committee reports does address the subsection (e)(1) limitation. ${ }^{53}$ The Senate Report indicates that Congress considered the "days rented to total days used" formula only in the context of its use as a limit on vacation home deductions that are not independently deductible. 54

According to the Bolton court, the committee reports indicated that the formula described in subsection (e)(1) was not the appropriate method for allocating interest and taxes.55 Yet, as has been demonstrated, nothing in those reports states or implies any judgment regarding the propriety of using the subsection (e)(1) formula to make this allocation. ${ }^{56}$ Rather, it seems that Congress did not even consider a method of allocating interest and taxes. ${ }^{57}$

If a taxpayer exceeds the personal use limitations for the vacation home for a taxable year, the deductions attributable to the rental activity are limited to the amount by which the gross income derived from the rental activity exceeds the deductions otherwise allowable with respect to such rental activities (e.g., interest and certain taxes). For this purpose, deductions attributable to the rental activities are those items which are of a type allowable only as expenses incurred in connection with a trade or business or the production of income (e.g., sec. 162 or 212 ).

Id. (emphasis added).

As previously discussed, interest and taxes are deductible regardless of whether the property is held for the production of rental income. See supra notes 20-23 and accompanying text.

53. S. REP. No. 938, supra note 2, at 153-54. The Senate report provides:

If the personal use limitation applies, the allowable deductions would be determined after first determining the expenses of the vacation home which are allocable to the rental activities (in accordance with the new allocation rules).

....

In the case where there is any personal use of a vacation home during the taxpayer's taxable year, the expenses allocable to the rental of the vacation home will be limited to an amount which bears the same ratio to such expenses as the number of days the home is actually rented out for the year bears to the total number of days the home is actually used for all purposes during the year. However, the limitation upon alloeable expenses would not apply to expenses such as interest or taxes which are allowable even if not attributable to the rental activity.

Id.

54. Id.

55. Bolton, 694 F.2d at 563.

56. Professor Lang believes that the court's interpretation of the legislative history is based on its misquotation of the committee reports. Lang, supra note 14, at 328-29.

57. One commentator believes that Congress thought the allocation of interest and taxes over the entire year was so patently obvious that Congress did not believe it was necessary to state it. Lathen, Bolton: IRS "Bizarre" on Section 280A(e), 60 TAXES 237, 239 (1982), noted in Bolton, 694 F.2d at 564. This analysis, however, suggests that Congress failed to consider the problem. Such a congressional oversight is not uncommon and is usually remedied by a technical corrections act. See, e.g., Technical Corrections Act of 1982, Pub. L. No. 97-448, 96 Stat. 2365 (1983). Although the Bolton method is the proper method, it is not necessarily the obvious method.

The Bolton court also noted that the parenthetical reference to the "new allocation rules" in the committee reports could support the proposition that more than one new rule exists for allocating expenses to rental activities. Bolton, 694 F.2d at 562 n.12. The apparent inference is that Congress intended a new rule-other than the subsection (e)(1) rule-for allocating both interest and taxes. This inference proves unwarranted when the committee reports are read as a whole; there is no 
Thus, to summarize, neither the statute nor the legislative history explicitly provides a method for allocating interest and taxes. Although the Bolton court construed the language of subsection (e)(2) to explicitly preclude the application of the "days rented to total days used" formula of subsection (e)(1) to taxes and interest, the prophylactic language used in drafting subsection (e)(2) appears nowhere in the legislative history of section 280A. Although subsection (e)(2) provides that subsection (e), in its entirety, does not apply to interest and taxes, ${ }^{58}$ the committee reports provide only that "the limitation upon allocable expenses would not apply to" interest and taxes. ${ }^{59}$

The most likely conclusion to be derived from this analysis is that Congress did not consider a method for allocating interest and taxes between personal and rental use; therefore, support for the method adopted in Bolton must be derived from sources outside the statute and its legislative history.

\section{The "Days Rented to Total Days of The YeaR" Formula Is MORE CONSISTENT With THE RATIONALE OF SECTION 280A}

The Bolton court relied primarily on an analysis of the statute and its legislative history in reaching its decision to reject the Commissioner's method of allocation. ${ }^{60}$ The statute and the legislative history do not indicate that Congress considered a specific method of allocating interest and taxes. ${ }^{61}$ Nevertheless, a comparison of the allocation formula adopted by the Bolton court with the formula proposed by the Commissioner, and an examination of the legislative history of section $280 \mathrm{~A}$, demonstrate that the Bolton method better achieves the underlying objectives of section 280A. ${ }^{62}$ Furthermore, the Bolton formula recognizes certain characteristics that distinguish interest and taxes from other

allusion to any new allocation rule other than that of subsection (e)(1). Although the plural form of "rule" was used, Congress was apparently referring only to the subsection (e)(1) rule.

58. See supra notes $45-48$ and accompanying text.

59. See supra note 53.

60. Bolton, 694 F.2d at 561-63. The court stated:

Thus, while the committee reports provide no guidance as to the specific method of allocating interest and taxes, they nevertheless show that the intent of Congress is contrary to the position taken by the Commissioner, and that use of the fraction found in subsection (e)(1) is not appropriate for allocating interest and taxes. This parallels the apparent intent of the facial language of $\S 280 \mathrm{~A}(\mathrm{e})(2)$. In sum, neither the language on the face of $\S 280 \mathrm{~A}$ nor its legislative history supports the Commissioner's position with regard to interest and tax allocation under $\S 280 \mathrm{~A}$.

Id. at 563.

61. See supra notes $45-59$ and accompanying text.

62. See infra notes $65-87$ and accompanying text. 
expenses related to the property, ${ }^{63}$ and considers the owner's goal of realizing future appreciation in the value of the vacation home. ${ }^{64}$

\section{A. Congressional Objectives Underlying Section 280A.}

Congress enacted section $280 \mathrm{~A}$ because it was concerned that nondeductible personal expenses were being converted into deductible expenses. ${ }^{65}$ Under prior law, no himitation was placed on the deduction of ordinary and necessary expenses incurred in connection with an activity aimed at making a profit. ${ }^{66}$ The crucial inquiry under this scheme was, of course, whether the activity was engaged in with the objective of making a profit. Even if an activity did not pass this subjective test, the deductions were still allowed subject to the limitation of section $183(\mathrm{~b}){ }^{67}$ This limitation was similar to the present section $280 \mathrm{~A}(\mathrm{c})(5)$ "gross income" limitation; pursuant to section 183(b), however, gross income from the activity was reduced by the entire amount of those deductions attributable to the activity that were allowable without regard to whether the activity was engaged in for profit - that is, interest and taxes. ${ }^{68}$ Thus, no allocation between rental and personal use was permitted for interest and taxes. This resulted in a smaller deduction for expenses that were not otherwise deductible.

Congress believed that inany owners of vacation homes-owners who used their homes for both rental and personal purposes-were improperly treating their ownership of vacation homes as an activity engaged in for profit. 69 By enacting section 280A, Congress intended to

63. See infra notes 88-96 and accompanying text.

64. See infra notes 97-106 and accompanying text.

65. S. REP. No. 938, supra note 2, at 151, provides, in the section titled Reasons for change, that "[w] here expenses attributable to a residence are treated as deductible business expenses, an opportunity exists to convert nondeductible personal, living and family expenses into deductible expenses."

66. Id. at 150 .

67. Id. Section 183(b) of the Code provides as follows:

(b) Deductions allowable. In the case of an activity not engaged in for profit to which subsection (a) applies, there should be allowed-

(1) the deductions which would be allowable under this chapter for the taxable year without regard to whether or not such activity is engaged in for profit, and

(2) a deduction equal to the amount of the deductions which would be allowable under this chapter for the taxable year only if such activity were engaged in for profit, but only to the extent that the gross income derived from such activity for the taxable year exceeds the deductions allowable by reason of paragraph (1).

I.R.C. $\S 183(\mathrm{~b})$ (1982).

68. I.R.C. § 183(b)(2) (1982); see supra note 67.

69. S. REP. No. 938, supra note 2, at 151-52, provides:

In the case of so-called "vacation homes" that are used both for personal purposes and for rental purposes, the committee believes that frequently personal motives predominate and the rental activities are undertaken to minimize the expenses of ownership of the property rather than to make an economic profit. 
establish definitive, objective rules to close this loophole. ${ }^{70}$

The operative word throughout the legislative history of section $280 \mathrm{~A}$ is "limit."71 It appears that Congress intended to limit deductions for expenses not otherwise deductible if-based on the objective personal use test-the primary purpose of the vacation home is personal use, with rental activities undertaken primarily to minimize personal expenses. Congress thus sought to prevent the conversion of otherwise nondeductible outlays into deductible expenses.

The method of allocating interest and taxes between personal and rental use adopted by the Bolton court is consistent with the explicit congressional goal of preventing the deduction of personal expenses. In contrast, the "days rented to total days used" formula advocated by the Commissioner not only prevents the deduction of personal expenses, but excessively limits the deduction of expenses properly allocable to rental use, thereby exceeding the congressional mandate of section $280 \mathrm{~A}$. The Tax Court noted that the Commissioner's method fails to acknowledge that interest and property taxes are deductible in full regardless of whether the property is rented at all. ${ }^{72}$ If the Boltons had not rented their vacation home at all, their net taxable loss from the property would have been $\$ 3475$, due to the deduction of interest and taxes. ${ }^{73}$ Using the Bolton method of allocating interest and taxes, the net taxable loss from the property rented as a vacation home was $\$ 2607 . .^{74}$ Using the Commissioner's method, the Boltons would have had a net taxable loss of only

70. The Senate Report provides:

The committee believes that definitive rules should be provided to specify the extent to which personal use would result in the disallowance of certain deductions in excess of gross income. In a case where personal use is the controlling factor to be considered, this approach would obviate the need to require subjective determinations to be made concerning the taxpayer's motive and the primary purpose for which the vacation home is held.

Id. at 152.

71. The Senate Report states that:

The [Act] adds a new provision (sec. 280[A]) which, in general, provides a limitation on the amount allowable to a taxpayer for the deductions attributable to the rental of a vacation home if the taxpayer personally uses the home in excess of specified periods of time during a taxable year.

....

If a taxpayer exceeds the personal use limitations for the vacation home for a taxable year, the deductions attributable to the rental activity are limited to the amount by which gross income derived from the rental activity exceeds the deductions otherwise allowable with respect to such rental activities (e.g., interest and certain taxes).

Id. at 152-53 (emphasis added).

72. Bolton v. Commissioner, 77 T.C. 104, 112 (1981).

73. This figure is determined by adding the $\$ 2854$ in interest and the $\$ 621$ in taxes. See supra note 35 and accompanying text. As previously discussed, interest and taxes are fully deductible regardless of whether there is any rental use of the vacation home. See supra notes 19-23 and accompanying text.

74. Using the Bolton facts, see supra notes $34-36$ and accompanying text, the net taxable loss is calculated as follows: 
$\$ 869.75$ Under the Bolton method, there is no conversion of nondeductible expenses into deductible expenses; the net taxable loss resulting from the Bolton method is actually less than the net taxable loss that would result if the Boltons had not rented their vacation home at all.

A comparison of this result with the rules predating section $280 \mathrm{~A}^{76}$ shows that the Bolton method is more consistent with Congressional objectives underlying section $280 \mathrm{~A}$. If the former rules applied, the Boltons would probably maintain that they acquired the vacation home for the purpose of making a profit. Assuming that the rental activity was undertaken for profit, there would then be no limitation on the deductions associated with the vacation home. The net taxable loss from the Bolton's vacation home im such a case might surpass $\$ 4468 .{ }^{77}$ This amount exceeds the net taxable loss of $\$ 3475$ that would result if the property was not rented at all. ${ }^{78}$ Thus, by claiming that the property was held for profit, the owners would convert normally nondeductible maintenance and depreciation expenses into a greater net taxable loss. This is

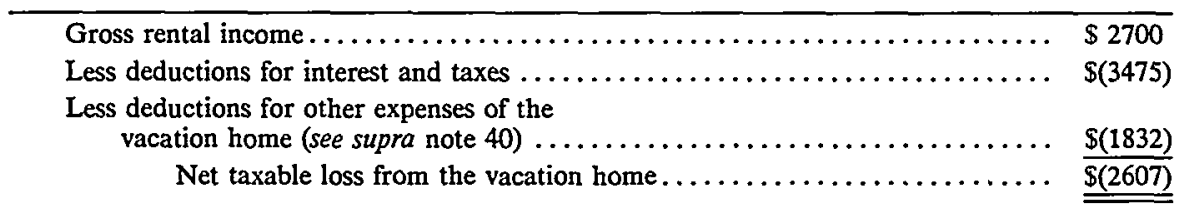

75. Using the Bolton facts, see supra notes $34-36$ and accompanying text, the net taxable loss is calculated as follows:

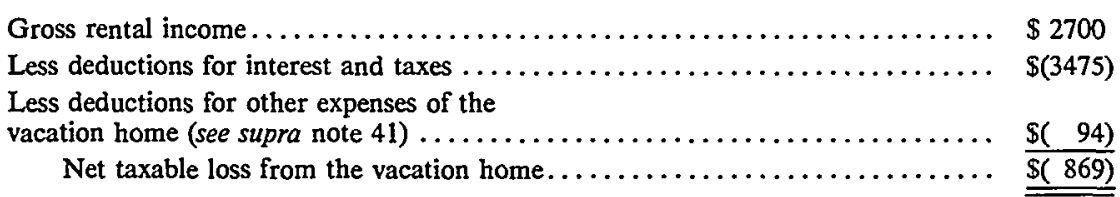

76. See supra notes 65-69 and accompanying text.

77. For purposes of this illustration, assume that the vacation home was purchased or built for $\$ 40,000$ and was expected to last for 40 years. A conservative calculation of the annual depreciation is $\$ 1000$, based on the actual useful life of the building under the straight-line method of depreciation. This was an appropriate method for calculating depreciation under the Internal Revenue Code in effect when this case arose in 1976. A taxpayer could also have elected to use an accelerated depreciation method. See I.R.C. $\$ 167$ (1976) (amended 1978, 1980, 1981, 1983, 1984). Today, depreciation would be calculated under section 168 as enacted by the Economic Recovery Tax Act of 1981, Pub. L. No. 97-34, § 201(a), 95 Stat. 172, 203 (codified at 26 U.S.C. $§ 168$ (1982)). Section 168(b)(2) also permits the calculation of depreciation at an accelerated rate.

The net taxable loss from the vacation home would be calculated as follows (see supra notes 35 36 and accompanying text):

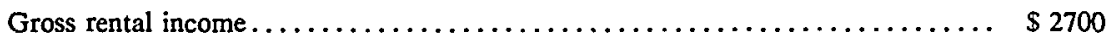

Less deductions for interest and taxes $\ldots \ldots \ldots \ldots \ldots \ldots \ldots \ldots \ldots \ldots \ldots \ldots \ldots$. $\$ \ldots \ldots 75)$

Less deductions for maintenance expenses $\ldots \ldots \ldots \ldots \ldots \ldots \ldots \ldots \ldots \ldots \ldots \ldots . \$ \ldots(2693)$

Less deduction for depreciation $\ldots \ldots \ldots \ldots \ldots \ldots \ldots \ldots \ldots \ldots \ldots \ldots \ldots \ldots \ldots, \$ \ldots(1000)$

Net taxable loss $\ldots \ldots \ldots \ldots \ldots \ldots \ldots \ldots \ldots \ldots \ldots \ldots \ldots \ldots \ldots$.

78. See supra note 73 and accompanying text. 
the conversion that section 280A was intended to prevent. This section's definitive, objective rules replaced the subjective determination of whether personal motives predominate. ${ }^{79}$

Congress did, however, require that some portion of interest and taxes be allocated to the rental activity for the purpose of calculating the section $280 \mathrm{~A}(\mathrm{c})(5)$ gross income himitation. ${ }^{80}$ The inevitable result of this allocation in the Bolton situation is that the taxpayer's net taxable loss in the case of rental of the vacation home will be less than the net taxable loss in the case of nonrental. If Congress only intended to prevent the conversion of nondeductible personal expenses into deductible rental expenses, the taxpayers in Bolton should have been permitted a deduction of no less than the total amount of interest and taxes for the year. ${ }^{81}$

Nevertheless, the elinination of past abuses was undoubtedly the primary purpose of section $280 \mathrm{~A} .{ }^{82}$ The Bolton method better achieves this goal. The Commissioner's method almost entirely elininates any deduction for maintenance expenses attributable to the rental of the vacation home, yet still requires the full inclusion of rental income. ${ }^{83}$ The Commissioner's nethod is, as the Tax Court stated, "overkill with a vengeance." 84

The fact that the Conimissioner's niethod of allocation is closer to the old section 183(b) "gross income limitation," in which all interest and taxes were subtracted from gross income in order to determine the allowable deduction, is irrelevant. ${ }^{85}$ Section $280 \mathrm{~A}(\mathrm{f})(3)$ provides that section 183 is inapplicable whenever the limitations of section $280 \mathrm{~A}(\mathrm{c})(5)$ apply. ${ }^{86}$ Furthermore, section $280 \mathrm{~A}$ (c)(5) expressly provides that interest and taxes must be allocated in some manner, whereas section 183(b) did not compel any allocation of interest and taxes between rental and personal use. ${ }^{87}$

79. See supra notes $69-71$ and accompanying text.

80. See supra notes $24-29$ and accompanying text.

81. See supra notes $\mathbf{7 3 - 7 5}$ and accompanying text. Compare the net taxable loss of $\$ 3475$ if the vacation home is not rented with net taxable losses of \$2607 and \$869-using, respectively, the Boltons' and Commissioner's methods-if the home is rented.

82. See supra notes $65-71$ and accompanying text.

83. See supra note 75 . The Commissioner would have allowed only $\$ 94$ of the total maintenance expenses of $\$ 2693$ to be deducted.

84. Bolton, 77 T.C. at 112.

85. See supra note 68 and accompanying text.

86. Section $280 \mathrm{~A}(\mathrm{f})(3)$ provides that section 183 is inapplicable when section $280 \mathrm{~A}(\mathrm{a})$ applies. Section $280 \mathrm{~A}(\mathrm{c})(5)$ is merely a limitation on the deductions that may be taken notwithstanding section $280 \mathrm{~A}(\mathrm{a})$.

87. In effect, all interest and taxes were allocated to rental usc. See supra note 68 and accompanying text. 


\section{B. Nature of Interest and Taxes.}

The very nature of interest and taxes may justify a different method of allocating those expenses. Interest and real property taxes are costs of owning and carrying the property-carrying costs-throughout the year. Other expenses such as maintenance, insurance, and depreciation are more commonly associated with use of the property. When a property is used heavily, it will generally require more maintenance and will probably wear out sooner. ${ }^{88}$ The Bolton court recognized that maintenance expenses tend to vary with the occupancy rate. ${ }^{89}$ On the other hand, some maintenance expenses will accrue regardless of the property's level of use. Maintenance expenses that result from forces of nature-sun, rain, freezing temperatures, and termites-are a good example. These same forces will also affect the depreciation of a building; in fact, depreciation expense accrues ratably during the year and its calculation is unaffected by occupancy of the building.

Although maintenance, insurance, and depreciation expenses do not lend themselves to definite characterization, there is no doubt that inter-

88. The Internal Revenue Code itself recognizes this distinction in another context. Section 266 permits the taxpayer to capitalize carrying costs to the cost of the property rather than allowing an immediate deduction for them. I.R.C. $\$ 266$ (1982). With respect to improved real property, capitalizeable carrying costs include interest and taxes, Treas. Reg. $\$ 1.266-1(b)(1)(i i)(a),(b)(1958)$, and any other carrying costs that, in the opinion of the Commissioner, under sound accounting principles, are chargeable to the capital account, Treas. Reg. § 1.266-1(b)(1)(iv) (1958). In Rev. Rul. 71-475, 1971-2 C.B. 304, the IRS held that advertising expense and the expenses of maintenance and upkeep are not carrying charges within the meaning of section 266. Id. at 304. Capitalization of carrying costs for improved real property is limited to the period of construction or development (during which the property is unproductive). Treas. Reg. \$1.266-1(b)(1)(ii)(d) (1958).

Rev. Rul. 71-475 did not discuss whether insurance constitutes a carrying charge under section 266; the I.R.S. has apparently not ruled on whether insurance is a carrying cost. In Gulf Atlantic Transportation Co. v. United States, 1956-2 U.S. Tax Cas. (CCH) If 10,052 (S.D. Fla. 1956), the court treated insurance as a capitalizeable carrying cost under section 24(a)(7) of the Internal Revenue Code of 1939, which was the predecessor of current section 266 of the Internal Revenue Code of 1954. Id. at 56,744. The court, however, did not discuss why insurance was a carrying cost or how it was similar to interest and taxes. In Gulf Atlantic, insurancc was incurred on a ship that remained docked for the entire time that it was owned by the taxpayer; it was never used for its intended purpose as a ferry. Id. at 56,743. It was used, however, in an auxiliary, supportive role as a floating machine shop for the other boats owned by the taxpayer. Id. The insurance in this situation could constitute a cost of carrying the vessel until it is operated in its intended capacity as a ferry. Such an interpretation would be consistent with the generally accepted accounting principle that provides that "[c]osts incurred on real estate for property taxes and insurance shall be capitalized as property cost only during the periods in which activities necessary to get the property ready for its intended use are in progress." Financial Accounting Standards BoARd, CURRENT TeXt, INDUSTRY StANDARDS AS OF JUNe 1, $1983 \S$ Re 2.106 (Am. Inst. of Certified Pub. Accountants) (1983). Thus, insurance might not constitute a carrying cost for a vacation home that is completed and in use. In fact, insurance in such a case is similar to maintenance costs and provides a means of indemnifying the more expensive maintenancc costs that can result from the use, or misuse, of the vacation home.

89. Bolton, 694 F.2d at 564 . 
est and real property taxes are continuing carrying costs. Interest is a charge for the use of money..$^{90}$ It is a cost of carrying the property that is not dependent on the property's use and which accrues on a daily basis. ${ }^{91}$ Similarly, real property taxes are a tax on the privilege of ownership. The owner is generally the person taxed, regardless of how the property is used. ${ }^{92}$ The ratable accrual of real estate taxes on a daily basis is illustrated by the application of section $164(d)(1)$ to real property sold during the taxable year. That section provides that real estate taxes be allocated between the new and former owners based on the number of days in the tax year that the property was owned by each. ${ }^{93}$ Because interest and taxes accrue to the owner of the property on a daily basis throughout the year, they should be allocated to any activity during the year based on the ratio of the number of days of the activity to the number of days in the year.

Perhaps the most basic distinction between interest and taxes and the other types of expenses associated with a vacation home is the manner of activity necessary to trigger deductibility. Interest and taxes are fully deductible when paid or accrued, regardless of the use of the vacation home. ${ }^{94}$ It is the actual use of the property, on the other hand, that controls the deductibility of the other types of expenses. Before the enactment of section $280 \mathrm{~A}$, such expenses were deductible only if the prop-

90. See, e.g., I.R.C. $\S 461(\mathrm{~g})(1)(\mathrm{A})$ (referring to interest as representing "a charge for the use or forbearance of money"); S. REP. No. 938, supra note 2, at 103-04 (Senate report pertaining to enactment of I.R.C. $\$ 461(\mathrm{~g})$, which recognizes nature of interest as chargc for use or forbearance of money or as cost of borrowed funds).

91. See, e.g., Anderson v. Commissioner, 568 F.2d 386, 389 (5th Cir. 1978); Burck v. Commissioner, 533 F.2d 768, 769 (2d Cir. 1976). These cases illustrate the concept of interest as a daily cost of borrowed funds. In both cases, prepaid interest was allocated among taxable years on a daily, 365-day-per-year basis.

92. See, e.g., Stephens v. Reed, 121 F.2d 696, 698 (3d Cir. 1941) ("liability for taxes upon property attends the ownership thereof'). As a general rule, property under a lease is taxable to the owner, not to the tenant. See, e.g., South Carolina Pub. Serv. Auth. v. 11,754.8 Acres of Land, More or Less, 123 F.2d 738, 741 (4th Cir. 1941) (under South Carolina law, "[i]t is clear that the obligation to pay the taxes on land must rest upon the holder of legal title rather than on whoever may have possession").

93. I.R.C. $\S 164(d)(1)$ (1982). For example, assume that real property taxes are assessed for the calendar year on January 1, but are not payable until the end of that year, December 31. Assume that $A$, the owner of that property on January 1 , sells the property on July 15 to $B$. Assuming that both $A$ and $B$ use the cash method of accounting, $A$ would deduct 195/365 (January 1 to July 14) of the property taxes payable for that year, even though he does not pay them, and $B$ would deduct $170 / 365$ (July 15 to December 31 ) of the taxes.

94. I.R.C. $\S 163(\mathrm{a})$ (1982) ("There shall be allowed as a deduction all interest paid or accrued within the taxable year on indebtedness."); I.R.C. $\$ 164($ a) (1982) ("Except as otherwise provided in this section, the following taxes shall be allowed as a deduction for the taxable year within which paid or accrued: (1) State and local, and foreign, real property taxes."). As previously discussed, interest and taxes are fully deductible regardless of the use of the property. See supra notes 19-23 and accompanying text. 
erty was used with the primary objective of making a profit. ${ }^{95}$ With the enactment of section 280A, the deductibility of such expenses became dependent on an allocation based on the rental use of the property. 96 Thus, an inquiry into the property's use is essential to determining the deductibility of those expenses under section 280A. No such inquiry is necessary for interest and taxes. Because they accrue on a daily basis, an allocation of interest and taxes based on the number of days in the yearas approved by the Bolton court-seems appropriate.

\section{Owner's Reasons for Purchasing a Vacation Home-The Investment Rationale.}

The allocation of interest and taxes based on the Commissioner's "days rented to total days used" method ignores an important personal objective in the purchase of a vacation home. Although the primary purpose of buying a vacation home may be personal use of the unit, a significant investment objective related to potential appreciation in the value of the property may accompany this purpose. ${ }^{97}$ As illustrated in Bolton, owners seldom recoup all of their costs by renting. 98 Interest and taxes accrue daily and represent the cost of carrying the property-the investment-for the full year, regardless of its use. Allocation based on the number of days in the year rather than just the days used would recog-

95. See supra note 66 and accompanying text.

96. See supra notes $16-17$ and accompanying text.

97. This appreciation could be expected to accrue ratably throughout the year-on a day-byday basis.

If there is no appreciation potential, then the taxpayer's incentive to buy a vacation home that is going to sit vacant for most of the year will decrease. Renting a vacation home in this situation might make more economic sense.

Purchased vacation homes may be distinguishable in this respect from perpetual use of a resort condominium acquired on a time-sharing basis. When a person purchases a time-sharing unit, he is purchasing the right to use that unit for a particular period of time each year; he is not purchasing an interest in a unit that will sit idle for most of the time that he owns it. In his article, Professor Lang attempts to show the invalidity of the Bolton allocation method by analogizing the purchase of a vacation home with the purchase of a time-sharing interest in a resort condominium. Lang, supra note 14, at 335-36. He bases his comparison, however, only on the similar periods of actual use of the two types of properties and fails to consider the reason why the purchaser of a vacation home is willing to carry the property during substantial periods of idleness-its value as an investment. A proposed treasury regulation, 48 Fed. Reg. 33,320 (1983) (to be codified at Treas. Reg. $\$ 1.280 \mathrm{~A}$ 3(f) (proposed July 2l, 1983), provides special rules for time-sharing arrangements, but those rules do not discuss the allocation of interest and taxes.

98. The Boltons incurred total costs of $\$ 6168$ (\$2854 interest, $\$ 621$ taxes, and $\$ 2693$ in maintenance expenses) and only recouped $\$ 2700$ through rental. See supra notes $35-36$ and accompanying text. Furthermore, the $\$ 6168$ in total expenses does not include an allowance for physical deterioration of the building and resulting major repairs that will be periodically required. This discussion ignores the tax savings-which vary depending on the tax bracket of the individual owner-associated with the deduction of these expenses. Nevertheless, the net cost of ownership is still significant. 
nize the daily cost of carrying the investment both while in use and while sitting idle. 99

An analysis of the legislative history reveals that section $280 \mathrm{~A}$ was not intended to deny the investment objective of realizing a future gain from appreciation. Rather, section $280 \mathrm{~A}$ was intended to provide an objective means of determining the deductibility of expenses associated with the home that are not otherwise deductible. A determination of whether the predominant subjective intent of the taxpayer was personal use of the home or earning a profit from the rental of the home would no longer be required. Congress believed that "frequently personal motives predominate" in the purchase of a vacation home. 100 The legislative history further provides that section $280 \mathrm{~A}$ obviates "the need to require subjective determinations to be made concerning the taxpayer's motive and the primary purpose for which the vacation home is held." 101 The investment objective of future appreciation, however, should not be ignored in determining the appropriate method of allocating interest and taxes, a problem that Congress did not even consider in the legislative history. ${ }^{102}$

99. Some part of the vacancy period might be considered a normal incident of the rental use of a vacation home because the owner may fail to find a tenant for the portion of the year during which he wishes to rent the property. This is particularly the case with a seasonal resort property. An attempt to split vacant time into separate periods and allocate it to personal or rental use-based on whether the owner was seriously attempting to rent and whether there was a reasonable chancc of renting - would require a complex and arbitrary set of regulations. The formula adopted by the Bolton court-"days rented to total days of the year"-reasonably accounts for the investment objective of vacation home owners.

100. S. REP. No. 938, supra note 2, at 151-52.

101. Id. at 152 (emphasis added). The whole thrust of section $280 \mathrm{~A}$ is to substitute an objective standard in place of a subjective determination of whether the primary motivation for purchasing a vacation home is personal use, and then to limit the deduction of expenses associated with the home that are not ordinarily deductible without some rental use. See supra notes 69-71 and accompanying text.

102. See supra notes $49-59$ and accompanying text.

Under section 183, which applied to the rental of vacation homes before the enactmcnt of section $280 \mathrm{~A}$, the potential for appreciation was a factor that was taken into account in determining whether the acquisition and rental of the vacation home were entered into for the purpose of making a profit. Treas. Reg. $\S 1.183-2$ (b)(4) (1972) provides:

Expectation that assets used in activity may appreciate in value. The term "profit" cncompasses appreciation in the value of assets, such as land, used in the activity. Thus, the taxpayer may intend to derive a profit from the operation of the activity, and may also intend that, even if no profit from current operations is derived, an overall profit will result when appreciation in the value of land used in the activity is realized since income from the activity together with the appreciation of land will exceed expenses of operation.

In Copeland v. Commissioner, 41 T.C.M. (CCH) 253, $257-58$ (1980), the taxpayer had investigated the vacation home's potential for appreciation before purchasing the home. Even though the taxpayer incurred repeated losses from current operations, the court held that the taxpayer had engaged in the activity for the purpose of making a profit in accordance with section 183 because of the vacation home's potential for appreciation. Id. On the other hand, the mere fact that the taxpaycr was aware of the potential for appreciation does not automatically mean that the rental activity was 
The apparent inconsistency between recognizing an investment objective for the allocation of interest and taxes under section $280 \mathrm{~A}(\mathrm{c})(5)$ but not for the allocation of other expenses under subsection (e)(1) is misleading and irrelevant. ${ }^{103}$ There is no statutory requirement of consistency, and the legislative history does not imply one. ${ }^{104}$ Section $280 \mathrm{~A}$ was enacted to prevent the conversion of ordinarily nondeductible personal expenses into deductible rental expenses when personal use predominates; ${ }^{105}$ thus, logically, the allocation of these otherwise nondeductible expenses should be based on the use of the property. ${ }^{106}$ Because interest and taxes are fully deductible regardless of the use of the property, however, the appreciation objective should influence the allocation of those expenses. Allocation of interest and real estate taxes based on the number of days in the year would account for the daily cost of carrying the vacation home as an investment regardless of whether it was being used or sitting idle.

\section{CONCLUSION}

In section $280 \mathrm{~A}$, Congress provided a complex, objective scheme for limiting deductions when a vacation home is used for both rental and personal purposes, but completely omitted any explanation of how interest and taxes are to be allocated under subsection (c)(5). Although the Bolton court's reasoning may have been incomplete, the result reached was appropriate. The better method for the allocation of interest and taxes with regard to the rental use of vacation homes is the ratio of days rented to the total days in the year.

This issue has not been finally resolved. The best solution would be for Congress to correct this oversight by amending section $280 \mathrm{~A}$. In the absence of a Congressional directive, however, the method adopted by the Bolton court should be followed as more consistent with the legislative intent behind the enactment of the section. The method properly considers the different nature of interest and taxes when compared with other expenses associated with a vacation home. The Bolton method also

engaged in for the purpose of making a profit; the taxpayer must have investigated the prospects for appreciation before purchasing the vacation home. Beltran v. Commissioner, 43 T.C.M. (CCH) 892 , 899 (1982).

103. In his article, Professor Lang notes this inconsistency and questions why such investment use should merit consideration for purposes of section $280 \mathrm{~A}(\mathrm{c})(5)$ and not for purposes of section $280 \mathrm{~A}(\mathrm{e})(1)$. Lang, supra note 14 , at 331 n.37.

104. Interest and taxes are explicitly excluded from the subsection (e)(1) allocation by subsection (e)(2), and the statute is otherwise silent on the method of allocating interest and taxes. See supra notes 19-23 and accompanying text.

105. See supra notes $69-71$ and accompanying text.

106. See supra notes $94-96$ and accompanying text. 
effectuates the owner's purposes in purchasing a vacation home-to realize future appreciation as well as personal enjoyment.

Jeffrey T. Lawyer 